Article

\title{
Harvest Regulation for Multi-Resource Management, Old and New Approaches (Old and New)
}

\section{Martin Alfonso Mendoza ${ }^{1, *}$, Juan José Fajardo ${ }^{2, \dagger}$, Gonzalo Curiel ${ }^{3, \dagger}$, Francisco Domínguez ${ }^{4, \dagger}$, Maribel Apodaca ${ }^{5, \dagger}$, María Guadalupe Rodríguez-Camarillo ${ }^{5, \dagger}$ and Jesús Zepeta ${ }^{6, \dagger}$}

1 Colegio de Postgraduados, Campus Veracruz, Carretera Xalapa-Veracruz Km 88.5, Manlio Favio Altamirano, Veracruz 91690, Mexico

2 Consultoría Forestal Mascota SC, Zapata 96, Mascota, Jalisco 46900, Mexico;

E-Mail: jfajardo.mascota@gmail.com

3 Unidad de Manejo Forestal El Tuito S.C., Carretera Federal Melaque-Puerto Vallarta Km 170 s/n, El Tuito, Cabo Corrientes, Jalisco 48400, Mexico; E-Mail: eltuito@hotmail.com

4 Benemérita Universidad Autónoma de Puebla, Facultad de Ingeniería Agrohidráulica, Av. Universidad s/n, Barrio Benito Juárez, Tetela de Ocampo, Puebla 73640, Mexico; E-Mail: forestal_umar@hotmail.com

5 Colegio de Posgraduados, Campus Montecillo, Carretera México-Texcoco Km 36.5, Montecillo, Texcoco, México 56230, Mexico; E-Mails: apodaca2109@yahoo.com.mx (M.A.); camarillo11@hotmail.com (M.G.R.-C.)

6 Consultoría Forestal Mascota SC, Zapata 96, Mascota, Jalisco 46900, Mexico; E-Mail: jzepeta@hotmail.com

$\dagger$ These authors contributed equally to this work.

* Author to whom correspondence should be addressed; E-Mail: mmendoza@colpos.mx; Tel.: +1-229-201-0770 (ext. 64330); Fax: +1-229-920-7257.

Academic Editor: Plinio Sist

Received: 11 November 2014 / Accepted: 28 February 2015 / Published: 9 March 2015

Abstract: Current Mexican forest management is the product of a history that dates back to 1926. Earlier approaches were directly or indirectly aimed at attaining the normal forest model. Around 1980, multi-resource and environmental impact considerations were mandated for all private timber operations. Timber-oriented silviculture was deemed insufficient to take proper care of non-timber values in the forest. Concerns about water quality, biodiversity, and natural conservation were the motives for promoting voluntary best 
management practices, in 2012 and afterwards. In this research, two traditional Mexican forest management schemes, Sicodesi and Plan Costa, enhanced with best management practices, are compared to Mapa, a management method specifically designed to manage landscape attributes. Results from two successive forest inventories 10 and 13 years apart show that Sicodesi and Plan Costa, even when modified to comply with best management practices, failed to maintain proper stewardship of non-timber values. Mapa, however, employed multiple means to drive forest dynamics to fulfill multi-resource objectives, constrained by self-financing and competitive profitability. These capabilities in Mapa enabled some degree of control over non-timber values, but many more important processes occur beyond the property boundary, and beyond the planning scope considered in Mapa and all other forest planning methods.

Keywords: harvest scheduling; stewardship; silviculture; tropical silviculture; land tenure; Jalisco; Mexico

\section{Introduction}

This paper addresses the response of current management methods used in Mexico to an array of changing social demands on forests and the forest economic sector. These methods are designed by talented foresters following forestry theory. The contention in this paper is that public demands and expectations today exceed the designed capabilities of all traditional methods. When framing the timber production process in the context of microeconomic theory about externalities, some of the newer methods seem to have a better performance than the older approaches. If the trend persists, forestry theory might be dropped in favor of management schemes that follow neoclassical economic theory, as is the case in other production processes. This paper is an extended version of Mendoza [1], in session B-09b (64b) "What future for tropical silviculture?" of the XXIV World Congress of the International Union of Forest Research Organizations, Salt Lake City, UT, USA, 5-11 October 2014.

Deliberate, rational policies for timber harvest regulation have a long history. For the purposes of this paper, forestry is thought of as a trade that formally started up in Europe in the Middle Ages. Medieval kings imposed policies about the rate of harvest in crown forests, along with other measures that formalized previous traditions such as old Roman rights concerning harvesting firewood and other forest products. Reliability of the timber and fuelwood supply were the stated motives that drove forest policies in Europe from the 9th to 20th centuries [2,3]. These priorities superseded the importance of other products and services such as medicinal plants, hunting, grazing, etc.

Classical forest management models from the 19th century and their associated silvicultural systems guided forest science and technology up to the end of the 20th century [4]. The normal forest concept and the fully regulated forest were the paradigms sought by these forest management models [5].

The use of economic goals started in Europe in the middle of the 19th century. The Faustmann [6] model, with its controversial implications on intensive management of short rotations for even aged stands and plantations, did little to change the general trend of forestry. Tradition prevailed, and forestry continued as a business more concerned with the residual forest, the flow or products, and forest health 
than with economic values or business strategies [7]. In America, financial performance was a minor issue in public lands, but it was a serious goal in industrial forests $[5,7,8]$.

At the turn of the 20th century, the American forest scene became influenced by public concerns about environmental services, avoidance or handling of catastrophic events-particularly wildfires - and with cultural forest values involving not market products, but existence values [4]. This trend became global, affecting countries like Mexico. The non-timber issues discussion became a historic event that changed the fundamental principles of forestry. These new challenges demanded a new set of tools for decision making. Mathematical programming was no longer enough because the new game was a multi-objective, multi-criteria search for socially and legally acceptable options. Optimal solutions were inadequate because they satisfied only a small set of stakeholders. The new scenario required solutions agreeable to all meaningful parts, those in protagonist roles, and those affected by consequences of deliberate actions, even if solutions departed from mathematical optimality [9].

In essence, Mexican forest history loosely matches European history, but it has recently been influenced by the environmental movement. Nature services as defined in Daily et al. [10] were interpreted by public opinion and decision makers as more than mere economic externalities - as values that need specific attention and stewardship [11]. The cultural clash in Mexico between these two distinct lists of priorities and objectives is the subject matter of this paper.

In the case of Mexico, forestry was a government response to public concerns about timber and fuelwood. Formal forestry operations began in Mexico as a mandate from the first forest law of 1926 [12]. According to this first law, forests are a public concern because of the role of forest resources in sustaining rural development. Therefore, it is in the public's interest that forest land should not to be ruled by market forces alone. These concerns became management objectives that have remained into the present. Forestry policies have changed through the years, but not in essence. Regulations on forest practices started and remained focused on estimates of forested area, standing stock, and rate of removals [13]. The lack of corporate holdings and public forests sets the Mexican case apart of the rest of the world, where these two forms of land tenure are the most important ones.

Several harvest regulation schemes followed area and volume regulation up to around 1980. At this time the need to follow up on other resources and forest values appeared. Adding environmental monitoring and assessment schemes to timber regulation was a simple matter of increasing the number of variables measured and monitored through time, but the basic planning continued to be driven by timber production criteria. Silviculture itself did not change; it remained engrained in regimes that promoted regeneration, growth, and harvest of timber, except fragile sites. These were excluded from all management interventions but fire suppression and pest control.

In the 1980s, two of the methods presented here appeared: Sicodesi (Sistema de Conservación y Desarrollo Silvícola, or Silviculture for Conservation and Development System), and Plan Costa. Sicodesi was meant to apply multi-resource silviculture to temperate mixed pine forests [14]. Plan Costa was a regulation technique to manage multiple products and species in tropical forests [15]. The third method studied here is Mapa (Manejo de Paisajes, landscape management method). [16,17] have described this latter method. Silviculture and harvest regulation procedures in Mapa were meant to implement landscape ecology concepts, as in Oliver and Larson [18].

The three methods in this research were chosen to take advantage of documented cases where at least two successive forest inventories have supplied field data to support an assessment in terms of output 
and residual forest conditions. Management plans for these study cases, complemented with personal opinions from the owners, loggers and professional foresters in western Jalisco as well as published research, make up the bulk of the information for this research.

\section{Management Methods Studied}

\subsection{Sicodesi}

The silviculture conservation and development system (Sicodesi) was developed by a group of Mexican and Finnish foresters through a cooperative effort in 1977. Sicodesi is coded into a computer program with modules that calibrate its decision support system to the species and policies of a given temperate forest. Sicodesi has been in use in many different forest regions of Mexico, but the early trials occurred mainly in Oaxaca and Jalisco [14].

The Sicodesi software uses a silviculture simulation model, forest inventory data, and information on land owner needs and preferences to draft a timber management plan. The plan objectives include, but are not limited to:

- helping the forest owner design his own forest plan without the help of a professional forester;

- drafting a forest plan even if there is limited information about the ecology and history of a given forest region;

- generating a substantial timber sales revenue stream and employment for forest owners;

- defining stable and fair career advancement paths for administrative staff and forest workers;

- drafting land use planning and zoning designations;

- preventing erosion;

- regulating water run-off in the watershed;

- sustaining continuous and stable timber output;

- granting priority status to health concerns; and

- initiating a conversion process to eventually achieve a fully regulated normal forest.

In this paper only the timber regulation goals and environmental concerns will be considered.

Sicodesi is a planning tool with no particular silvicultural system attached, so a different system can be used for each case. Moreover, Sicodesi contains provisions for using several silvicultural systems in a single plan. It has been common practice that the mixture of pines, oaks, and other broadleaved species be treated with seedtree cut, or any of its variants, at the end of the technical rotation. It is also common to use the selection system to treat steep slopes, fragile soils, and low productivity forest types. Since stands have a previous history of development, it is unlikely that any of them will reach rotation age just in time for the final harvest of a certain annual cutting area, hence the harvest allocation algorithm uses rotation along with other criteria in setting a compromise harvest schedule. These other criteria include environmental factors like those listed above.

The harvest plan covers one 5-year period, following guidelines set for a 30-year planning horizon. The cutting cycle is 10 years in almost all cases. An assessment is carried out every 10 years, then the plan and the planning tools are updated and calibrated. 


\subsection{Plan Costa}

When managing natural tropical forests, many management methods in Mexico and in the world use diameter limit or some other measure of size in lieu of rotation age. Tropical natural forests tend to be complex mixtures of many species of trees and other plants. Plan Costa is an alternate option created for cases where diameter is a poor indicator of maturity [19]. The rationale of Plan Costa is that every site, every species, and every tree has a unique pattern of behavior weakly related to size or age. Plan Costa demands field prescriptions that take advantage of features that each group of neighboring trees exhibit.

Silviculture consists of only one treatment. The treatment removes a whole tree group in spots where there is a concentration of commercial timber, senile trees, and a composition that would be desirable to increase in the future. Harvested groups are placed scattered along annual cutting areas [19]. Group size is around 0.3 ha [15]. This size of opening fits the reproductive needs of most commercial timber species in the Pacific coast of Jalisco; smaller clearings will not regenerate, and larger ones will favor undesirable species.

A tally of frequencies in the initial forest is compared to a theoretical probabilistic distribution derived from Mèlard's French method, also known as the quartier bleu method [2]. The original French method allocates stands into one out of three compartments (quartiers) according to age. Plan Costa instead uses a set of anatomical features to assess the stage of development of a given tree [19]. Mature trees make up the yellow compartment. The most obvious features signaling maturity include a sound and solid stem, and prolific signs of reproductive capacity; these trees are the most valuable in terms of commercial products, and they are the most dependable source of seeds. The senile and overmature trees form the blue compartment. Senile individuals are those showing signs of decrepitude such as heart rot, epiphytes, and irregular crowns with uneven foliage. The pre-reproductive individuals are grouped into the white compartment. They usually are too young to reproduce, and they have no heartwood, only sapwood, and therefore have no commercial value. Despite the obvious differences, Plan Costa is true to the quartier bleu method in essence. The French method was meant to impose a policy of restricting final harvest to a third of the forest area, the blue compartment, with no specific time frame, nor any particular stand sequence [20]. The rationale for having a flexible harvest schedule is to deal with the unpredictable ecological situation in high elevation forests. When the entire blue compartment has been successfully regenerated, it becomes the white compartment. Only then do stands in the yellow compartment advance to become the blue compartment. This is the exact nature of Plan Costa: it is a means to deal with the uncertainties of numerous tropical species, and the diverse spatial variability in the forest.

Commercial forest land in Plan Costa is divided into equal annual cutting areas. Forest inventory estimates stocking. Marking rules apply group selection treatments in those spots where overmature trees are more abundant, if there are also enough mature valuable trees. Harvest intensity can be higher or lower-i.e., more or less groups removed, according to the needs of conversion towards the theoretical distribution of a normal forest. The rest of the forest is retained to provide presence and seeds of all species of a given forest type. The cutting cycle is 24 years long, but forest inventories occur every 10 years. 


\subsection{Mapa}

Mapa was the Mexican response to an international trend that redefined silviculture and forest management to fit the postmodern concerns, expectations, and technological limitations of recent times [21]. The goal in Mapa is to show that active management of commercial forests would provide a better and more reliable scheme of natural conservation, with no added expenditure of public funds [17].

If stands in a forest were classified according to the sequence of seral stages depicted by Oliver and Larson [18], and if transition from one stage to the subsequent stage is driven by a specific disturbance event, a silviculture system could be designed to replace these disturbance factors. Landscape silviculture can regulate the frequency, size, and location of future stand structures [17]. Then, it is possible to improve the current frequency and location of seral stages relative to a desired theoretical distribution. Landscape silviculture also provides ample flow of commercial forest products to the market.

Silviculture in Mapa is meant to reintroduce the theoretical disturbance pattern expected for the forest type (mixed pine, fir and hardwoods). A treatment could be designed to retain the current stand structure at least for the duration of the cycle. It can also be shaped to speed up change towards mature successional stages. Otherwise, it can be intended to drive a return to a previous stage. This latter goal usually means a stand replacement treatment that reestablishes a new even aged population (initiation phase in terms of Oliver and Larson [18].

Additional regimes in Mapa address the fact that roads and logging systems have permanent and severe impacts on the forest hydrology [22]. Thus road design should be inserted into silvicultural prescriptions by means of best management practices. Also, a special treatment regime is prescribed for special sites such as ridge tops, permanent and temporary openings, and riparian zones.

Monitoring of environmental variables and other non-timber forest values has so far not been mandatory, and very little of it is carried out in Mexico, except in the case of Mapa, where explicit goals exist for non-timber forest features. Mapa itself has no specific scheme to follow up single attributes; rather, Mapa follows a landscape approach where landscape diversity and health are assumed to be linked to the conditions and trends of most non-timber goals of interest to the forest planner. Mapa studied the diversity and spatial distribution of successional stages, their connectivity, integrity, interphases, and internal structure, as well as the disturbance patterns at the stand level and the tree level. Given an initial set of conditions, the Mapa scheduling heuristics select activities and policies to improve the distribution and spatial patterns of all successional stages present or likely to be attained in the span of one cutting cycle.

\subsection{The Cases}

\subsubsection{Sicodesi}

Corrales is a woodlot located in Mascota, Jalisco, Mexico (Figure 1). Vegetation type is a mixed temperate forest dominated by several pine species. Oak and other broadleaves make up the rest of the overstory composition. Climate is temperate with rainy summers. Site quality is good [14]. 


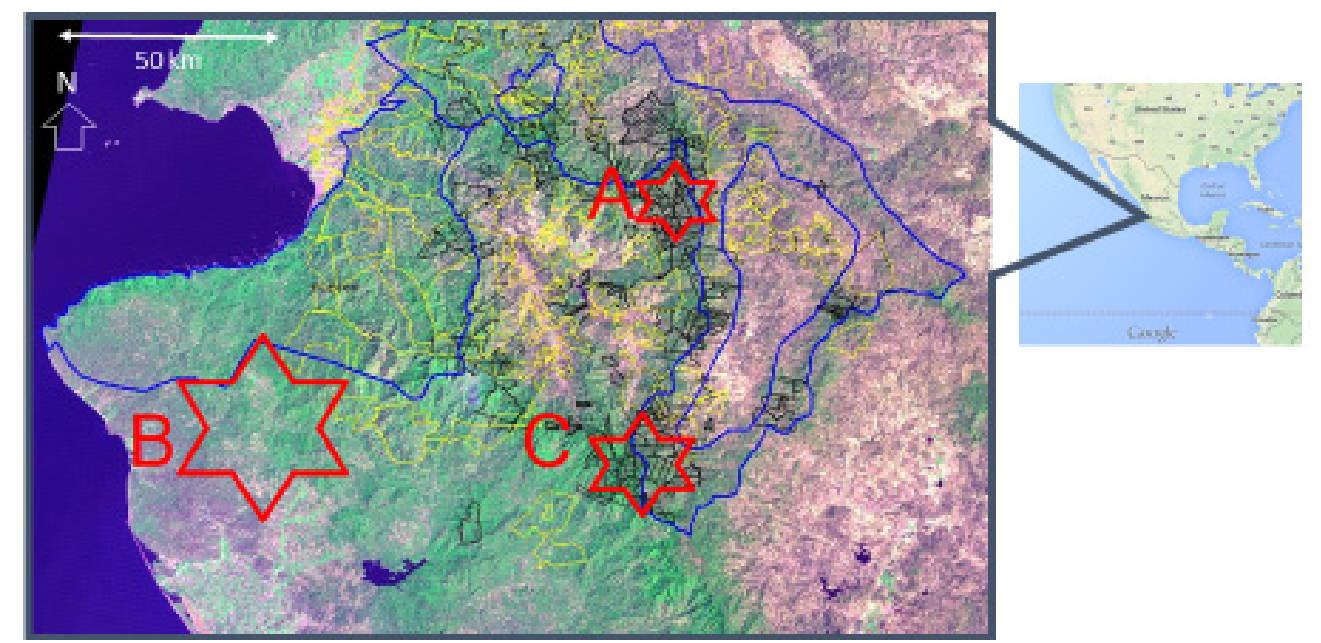

Figure 1. Study cases location. Corrales (A); Santa Cruz del Tuito (B); El Llanito y cuatro más $(\mathbf{C})$, Jalisco, México. Yellow and black lines are timberland property boundaries, blue line is the limit of the natural protected areas.

Corrales has been under Sicodesi since 1990. Reported here are the results after the first 10 years. The property is 1511 ha in total, with 427 ha of commercial timberland. Corrales was owned by a miner who had no interest in timber. He thought of holding the land as wealth to inherit. When the miner died, the property was managed by his widow and sons from 1990 to 2003 [14]. The place was then sold to a local logger and forest owner who currently manages this property in coordination with other woodlots to supply its own sawmills.

Forest planning at Corrales has been contracted to a group of professional foresters (Consultoría Ambiental Mascota SC), for more than 30 years [14]. Forest management policies have been stable ever since. The main policy has been to reclaim degraded places after pest and fire disturbances, while increasing timber stocking in the rest. Silvicultural regimes seek to approach full stocking as defined by targets from Sicodesi decision support system simulations.

\subsubsection{Plan Costa}

The Plan Costa method, developed in 1980, has been in use in the tropical forests of the Jalisco coast. Comunidad Indígena Santa Cruz del Tuito is one of the rural communities were Plan Costa has been applied more than once. This community is in Cabo Corrientes, Jalisco. The total area of Cruz del Tuito is 32,018 ha, but only 19,070 ha contain commercial forest cover. The commercial forest is composed of four distinct forested woodlots [19]. The main forest types in commercial timber land are medium tropical forest, low tropical forest, acacia brushland, oak forest, pine forest, and palms. Scattered trees, palms and other plants growing in the croplands and rangelands are also of value as forest products; one of those specialty products is the strangling fig tree, whose stems are in high demand for rural construction and decoration.

\subsubsection{Mapa}

The first ownership to be managed through landscape guidelines was a group of five contiguous properties known as "El Llanito y cuatro más", located in Atenguillo, Jalisco. These woodlots started on 
Mapa in 2002. The 2012 assessment is presented here. Owners in El Llanito belong to a single family. A representative was given legal powers to carry out timber sales in a coordinated way for all five properties. The total area of El Llanito covers 3357 ha, most of them commercial timberland supporting a mixed forest of pines, oaks, firs and other tree species [16,17]. The total area under Mapa management is 13,978 ha in 29 woodlots of the Sierra Occidental, Jalisco, Mexico.

\subsection{Performance Criteria}

Social demands are used here to assess methods performance. They are interpretations derived from law and regulations, as well as literature about the anthropology of Mexican identity. A selected list of what public administrators interpret as the citizen's will and preferences is provided by del Angel [11]. Mendoza et al. [23] describe the regional identity of the general public and the forest owners in western Jalisco, the region where this research's case studies occur. These two sources offer a good approximation of the social mandate for forests and forestry in Mexico.

The assessment process expects that each method will comply with merit criteria because of design features more than because of circumstances. The ultimate aim in this comparison is to ask if any of the past or current forest management methods have had the capability to guide forests according to social expectations. Deep insight might be possible if we look into the original design purposes of each method, and simultaneously inquire about historically changing social demands.

The following is a selected set of performance features. Forestry operations are expected to attain these goals when complying with most of the explicitly expressed wishes of Mexicans regarding the state of forests, the forest economic sector, and forest dependent communities:

1. Ownership stability and owner satisfaction

2. Non declining total and commercial forest area

3. Regulatory compliance

4. Non-declining standing stock before each entry

5. Steady and reliable output flow

6. Resistance and resilience against health hazards and extreme weather events

7. Steering away from conflicts about water resources

8. Sustenance of the characteristic ecological diversity of the region

9. Land value

10. Public access and outdoor activities

11. Favorable public opinion

12. Technological progress, strong scientific research, sophisticated forest culture

13. Opportune handling of public affairs: governance, precedent setting, leadership, public policies, value chain organization

\section{Results and Discussion}

Relevant outcomes regarding assessment criteria follow: 


\subsection{Stable Tenure and Forested Area}

The fact that the three properties studied remained forested and the land is still being used as forest shows continued interest from land owners in the forest business. The Corrales woodlot was sold during the cutting cycle (2002) because the owners wanted to move away from the region. For them the sale was a profit-taking choice. The new owner also owns two sawmills and several pieces of forest land. For the new owner, the acquisition of Corrales improves the set of supply options for his sawmills, and it is a smart purchase of a piece of forest land with a promising future.

Cruz del Tuito and Llanito remained in the hands of their original owners. Cruz del Tuito is an indigenous community whose members also have interests in ranching, an activity of larger importance than timber growing. Only a small minority of community members are directly involved in logging operations in the forest, or in the administrative work. Most of the timber is sold on the stump to loggers who develop specialty products out of the 97 species grown.

On the other hand, El Llanito owners consider themselves investors and executives who make decisions about the land. All roads, logging, and complementary activities are contracted to small local firms. The Sánchez family, owners of El Llanito y cuatro más, sets general goals by occasionally consulting all relatives. The general guidelines are implemented by the family legal representative. So far three generations have managed these and other pieces of forest land on a continuous basis, and they still have a vision of remaining in the timber-growing business indefinitely.

Tenure in these three cases conveys a sense of feasibility and stability for timber investments. This outcome satisfies the goal of stewardship of the land while partially sustaining income of rural households. The three forest management techniques studied might not be entirely responsible, but rather the owners' preferences and the prevailing regulatory conditions; not only the three methods studied here, but also most other forest management methods in current use in Mexico can be expected to yield the same outcome. Deforestation and forest degradation are processes that involve specific circumstances that are rarely present in timber lands under forest management.

Sicodesi is the only method with an explicit intention to promote rural development. The method was designed for national use. Its point of reference is an idealized profile of the peasant's preferences, needs, and capabilities [24]). The idea that rural development will be possible by providing income from timber growing, and jobs in logging, is an oversimplification in Sicodesi's rationale. In this research it became clear that the three cases studied are similar in terms of the land owners. The forest managers represent extended families. The general mandate for them is to increase the economic value of the land, proceeding in a risk-averse manner. The three owners studied, and most owners in this region, including owners of communal lands, prefer selling stumpage to independent loggers. They see no purpose in taking advantage of value-added activities such as silvicultural treatments or logging operations, so they contract them whenever possible.

Regardless of the kind of forest management, in this region compliance with tax, environmental, forest, and community regulations has been the norm throughout the time period studied. There have been no sanctions when law enforcement has reviewed the three study cases studied. 


\subsection{Planned and Actual Operations}

The three forest management plans were carried out as written, although schedule changes were made due to unexpected disturbances (fire and pests). The cases selected for this study were above average in terms of stewardship and responsible management, but in essence they differ little, in terms of how much of the plan was actually implemented, from any other forest plan in Mexico.

Sicodesi's application has benefited from the stable technical leadership that the local foresters at Consultoría Forestal Mascota SC have provided for over 30 years. Therefore, implementation in this region is closer to the Sicodesi design by the University of Helsinki's researchers. Some of the professional foresters in Mascota were part of the development team working in Helsinki.

Plan Costa's Cruz del Tuito is also a case of consistent forest management policies by a single forester, Gonzalo Millán Curiel Alcaráz. Curiel was involved in the group that developed Plan Costa, and afterwards he has applied it over 193,372 ha in the Pacific coast of Jalisco, for the last 30 years. In many ways it is difficult to separate results that come from the method, from the personal talent of the regional forester. This is particularly so in the case of decisions requiring knowledge about the silvics of particular species, and also in the skill to match field scenarios with wavering market preferences.

Removals, residual stock at the end of the 10 year planning horizon, changes in area occupied by the commercial forest, and net growth outcomes follow:

After 13 years - the second half of a cutting cycle - the new forest inventory of Cruz del Tuito reports Plan Costa has produced an enriched forest that contains increased presence of 10 out of the 12 most desirable timber species (Figure 2). One species, Enterolobium cyclocarpum, suffered severe heart rot mortality. The disease reduced E. cyclocarpum standing volume abundance from $45 \%$ to $18 \%$, though this is still a considerable presence that keeps this species among those with the largest share of forest biomass. This species was also abundant in ranching areas, unmanaged forests, and in backyards. These other E. cyclocarpum populations suffered catastrophic losses, much worse than in the Plan Costa managed forest. The success of regenerating most commercial species while keeping their volume stocking at reasonable levels and the site fully occupied by timber producing trees were accomplishments for Plan Costa that compare favorably with results in other tropical silviculture cases reported, such as those in Putz et al. [25], and Duah-Gyamfi et al. [26]. In 2003, Cruz del Tuito halted logging operations while a new administration implemented improved accounting procedures to correct clerical irregularities in the procurement chain; however, latter activities picked up the slack, so by 2010 all volume sold was already harvested and delivered to the final user. A sizable percentage of planned volume $(69.7 \%)$ was left standing on the forest for lack of market opportunities [27].

Plan Costa applied group selection cuts in Cruz del Tuito. Sicodesi treatments in Corrales consisted of seedtree cuts, shelterwood cuts, thinnings, light thinnings, and selective cuts. Mapa followed a unique stand-by-stand silviculture prescription favoring development of scarce late successional and initiation (regeneration) stand structures. The end of the planning horizon means renewal of management plans. The process involves an assessment of the previous planning period's performance. According to the most recent management plans, the quality of silviculture prescriptions is satisfactory in terms of the effect on the residual stand, for all management methods and silvicultural systems studied. 
PLAN COSTA

Cruz del Tuito

1997

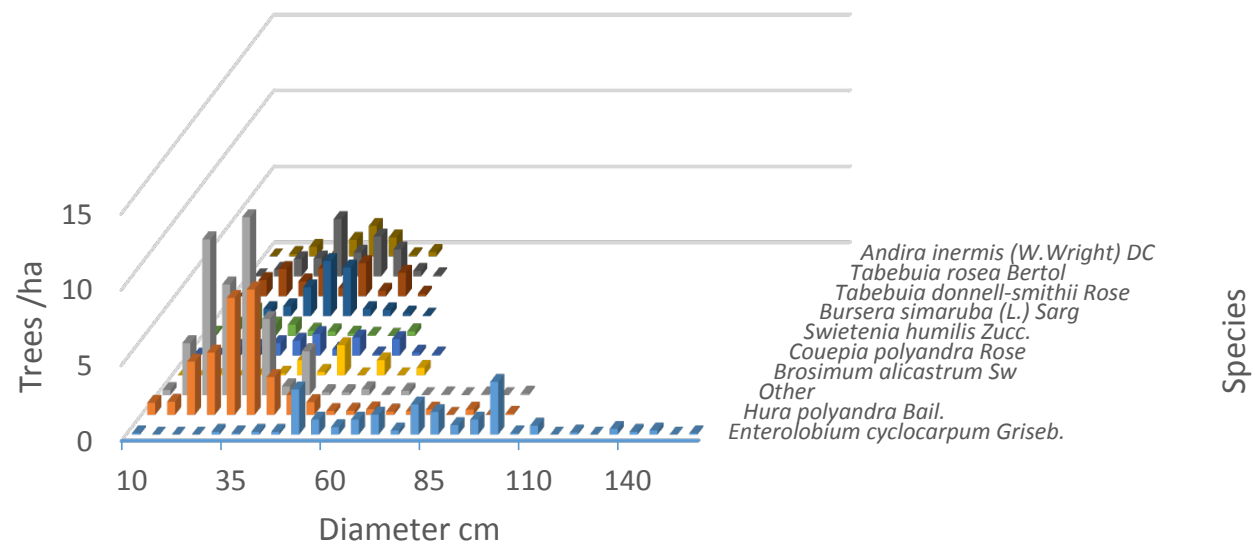

PLAN COSTA

Cruz del Tuito

2010

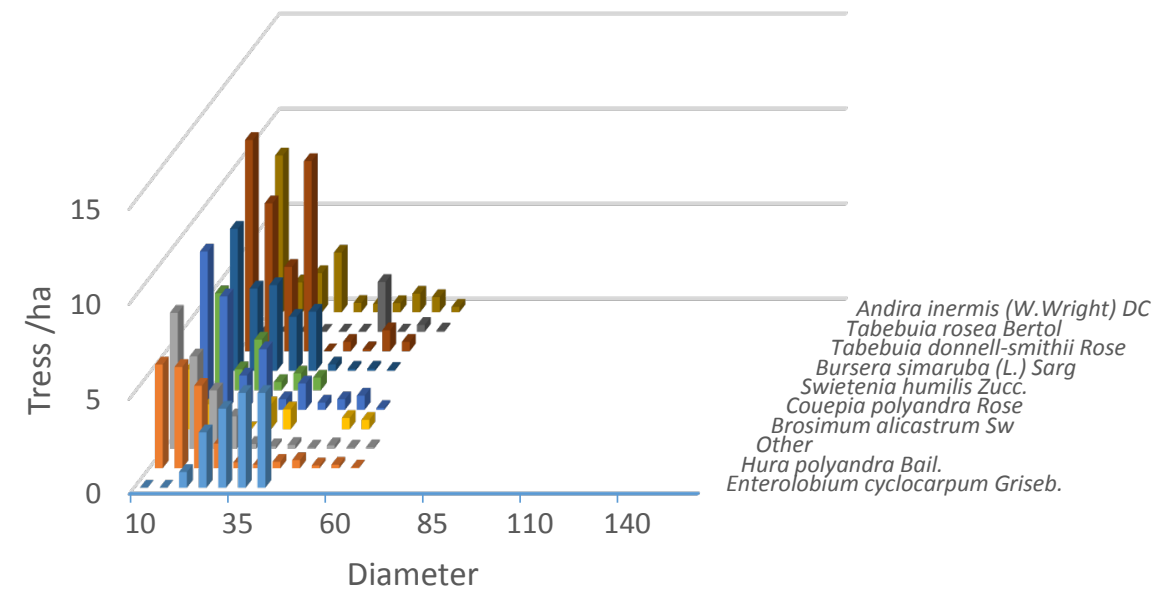

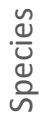

Figure 2. Diameter frequencies 1997-2010 of important timber species managed by PLAN COSTA in Comunidad Indígena Santa Cruz del Tuito, Jalisco, México.

Residual stocking in Mapa/Llanito increased marginally $(2.1 \%)$, while in the previous cycle (1992-2002), standing volume had diminished by $17 \%$ because of pests and fire damage. In the case of Sicodesi/Corrales and Plan Costa/Tuito, residual inventory tended to decrease. The downturn in Cruz del Tuito was 5\%. In Corrales' case the drop might appear steeper (9.2\%), but still acceptable performance. Actual stocking of the commercial stands in Corrales increased from $117.2 \mathrm{~m}^{3} / \mathrm{ha}$ to $145.7 \mathrm{~m}^{3} / \mathrm{ha}$. The Sicodesi simulation model forecasts that residual standing stock in Corrales will grow 
at a rate of $4.1 \mathrm{~m}^{3} / \mathrm{ha} /$ year during the next 30 years. In general, the three cases reflect a policy of increases in standing inventories, increases in tree size, and age (Figures 2-4).

\section{SICODESI}

\section{Corrales}

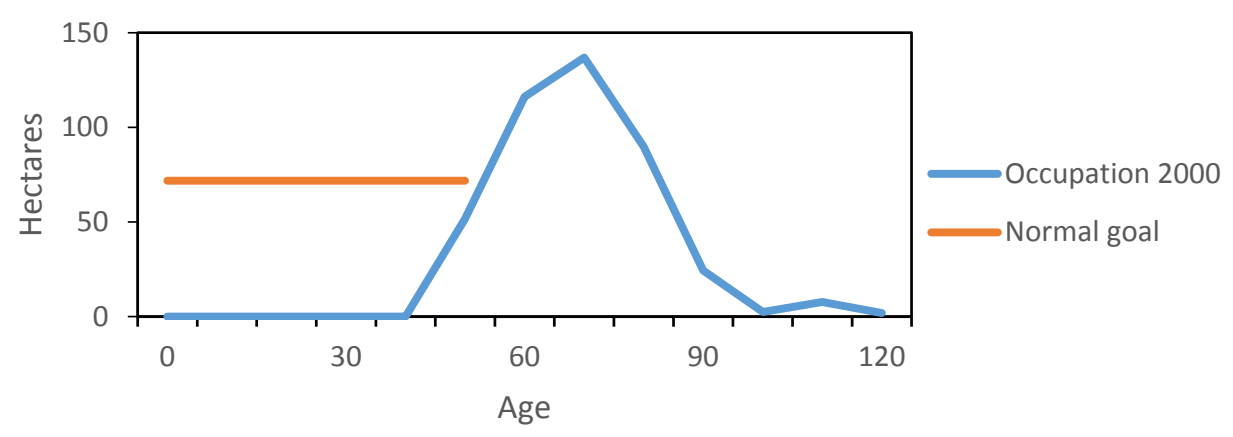

Figure 3. Goal and final (2000) age distribution in Corrales, managed under SICODESI.

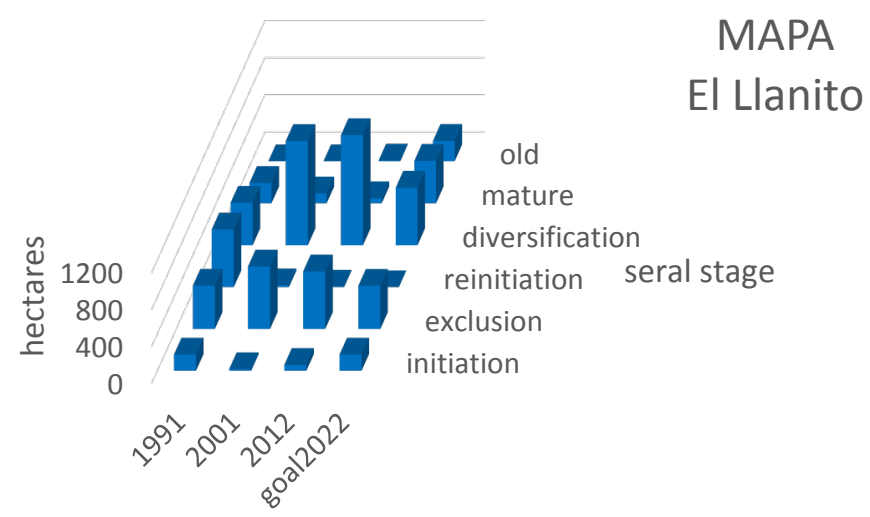

Figure 4. Starting (2002), residual (2012), and forecasted abundance of seral stages in El Llanito y cuatro más, managed under MAPA.

The region of Sierra Occidental where the cases are located went through a couple of difficult decades (1980-2000). There were numerous catastrophic wildfires, and afterwards mistletoe and barkbeetle infestations. The aftermath was a reduction of about a third of the regional biomass. The 2000-2010 decade was a time in which foresters wanted to build up forest cover, inventories, and resilience. All three methods and other regional forest management methods attained this goal through a policy of harvesting a fraction of the net growth, and investing vigorously in reforestation and site amelioration. Corrales was particularly successful, and it reached a remarkable improvement: $25.0 \%$ commercial forest land in 1990 rose to $42.6 \%$ in 2000 , as a result of reforestation and the protective management of stands affected by barkbeetles, mistletoe and fire.

This success in rebuilding the forest's productive potential definitely had an impact on net cash flow, a variable directly related to volume harvested. Sales revenues foregone in Plan Costa and Sicodesi were much worse than in Mapa, simply because Mapa has a financial assessment routine that identified better choices. Corrales invested heavily in land reclamation, while Cruz del Tuito left two thirds of the 
allowable cut in the forest. In the meantime, Llanito harvested close to the allowable cut, slightly less than the previous cycle when it was under Sicodesi.

As previously indicated, removals were conservative. It should therefore not be a surprise that timber output flow proceeded in a reliable way, with marginal fluctuations in Mapa/Llanito and Sicodesi/Corrales. When fire or pests were severe, salvage and sanitation cuts substituted the planned volumes harvested to sustain an even flow of products (Figures 5-7). It is important to add that El Llanito planned no cut in the 10th year of operations; this was for convenience of the timber procurement system, and it does not reflect a problem nor a planning error.

\section{PLAN COSTA}

removals

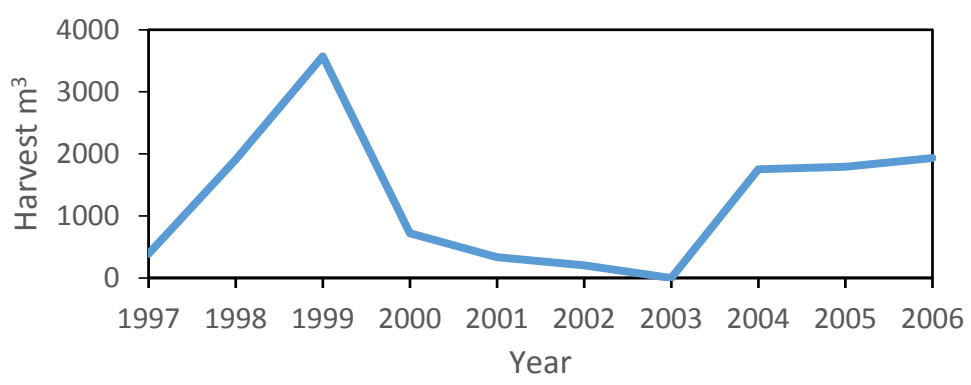

Figure 5. Harvest output in Comunidad Indígena Santa Cruz del Tuito, managed with Plan Costa.

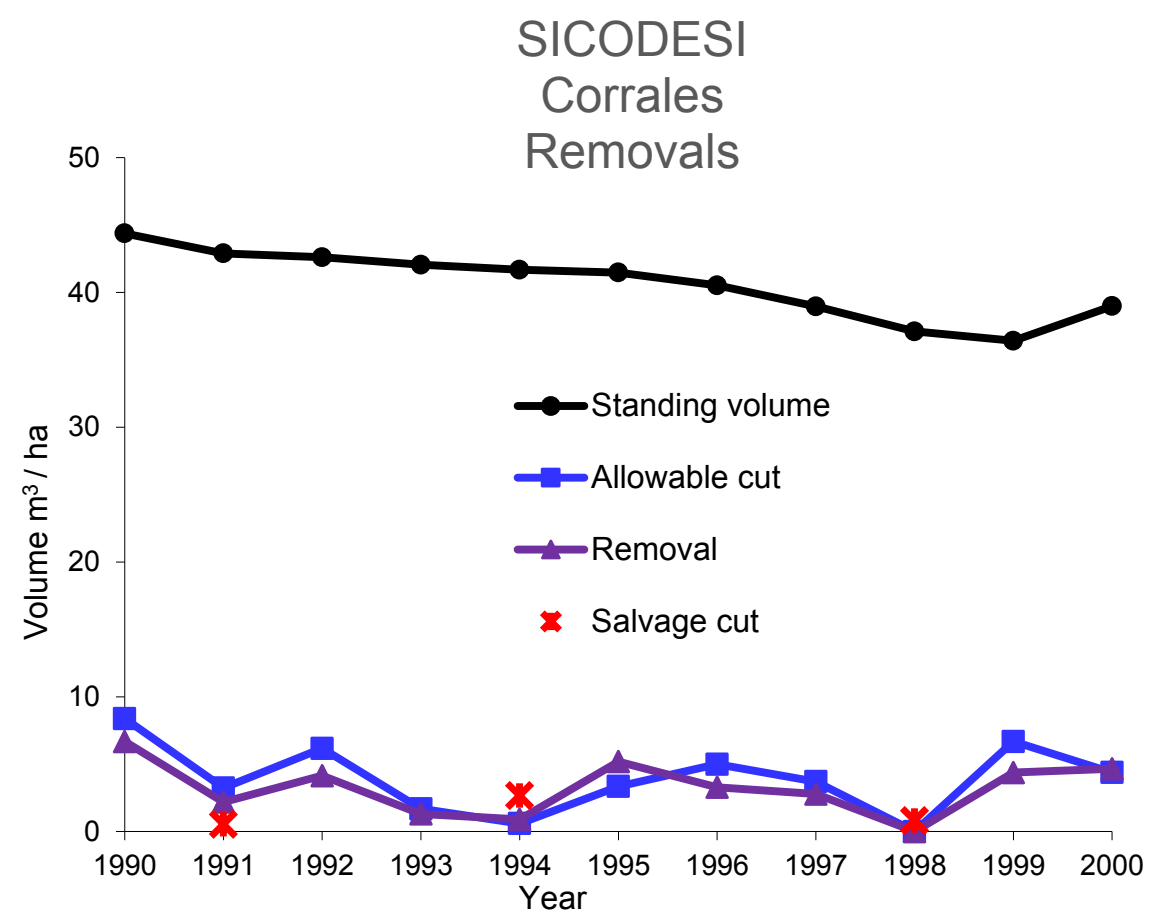

Figure 6. Harvest relative to standing stock by cutting area in Corrales, managed under Sicodesi. 


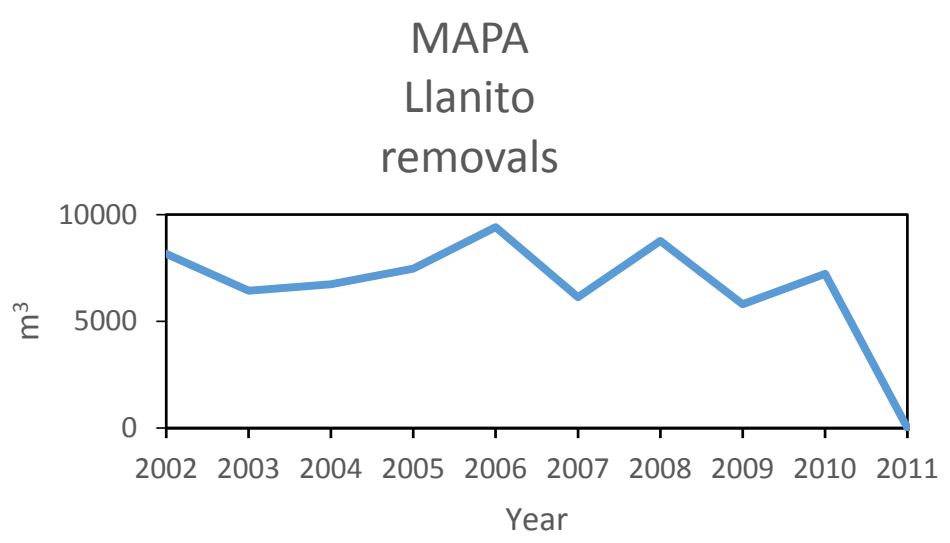

Figure 7. Output volume in El Llanito y cuatro más, managed by Mapa.

The Plan Costa/Cruz del Tuito case needs some additional explanation: community planners and the professional forester in charge intentionally plan excess silviculture opportunities so that every individual community member will have an array of different products in a given cutting area from which to draw the products solicited. When a given product is requested, if available, it will be sold, and only then marked, felled, transported, and tallied as harvested. Thus the apparent high percentage of planned cut that is not harvested (69\% in 10 years of operation) is an administrative buffer to assure high coverage of sales demanded. Shadow costs involved in this strategy are not relevant to the community members. The indigenous community of Santa Cruz del Tuito depends on diverse income producing activities, cattle raising being the most important one. Forest land is one more economic opportunity at the disposal of every single community member. Consequences in terms of timber growth, stand regeneration, health, or complex late successional stages are a matter of further study. Most likely, the current structure is still young and can go many more years with little or no silviculture interventions.

\subsection{Non Timber Values}

Plan Costa, Sicodesi and Mapa do not contain a comprehensive set of elements to address non-timber values. In the larger scenario of regional and national issues and concerns, none of the study cases has made any impact on any of the expected goals. Issues like migrant species, or large and symbolic species of wildlife such as jaguar, are a considered in the management plans and stand level operations, but information on habitat requirements, response to disturbance or to logging is incomplete for these species and forest values. Hence, the actual level of control over these matters is weak.

Mapa is disintct from the other two methods in following drastic policies known as biopaths to reintroduce the natural disturbance regime, and increase the presence of all successional stages. Mapa's emphasis has been in increasing area of regeneration and late seral scenarios because they are the least frequent stand structures. So far, after ten years of continuous landscape management, Mapa has not yet reshaped the geographic distribution and frequency of distinct ecological structures, those built by the previous cycle under Sicodesi. Rather, Mapa has maintained the general proportion seen in 2002 (Figure 4).

Nonetheless, the forest today in El Llanito offers a little more diversity and high quality habitat for wildlife thanks to careful attention to best management practices. The planned and actual distribution of 
seral stages in Llanito is seen in Figure 4. Comparing Llanito/Mapa with the respective frequencies of stand classes at Corrales/Sicodesi, and Tuito/Plan Costa, it seems subjectively that the guidance at Llanito/Mapa has paid it off in terms of a more diverse and rich set of scenarios. The improvement is striking compared with Sicodesi, since Sicodesi was the previous management method used in El Llanito, and it is reasonable to assume that Sicodesi might have continued if Mapa had not been employed in 2002.

According to Mexican environmental regulations, enforcement can only operate at the ownership level. There is no doubt that most of the important values beyond commodities occur at larger territorial levels [4], so the proportional contribution of forest stewardship through timber-oriented silviculture might be negligible in all cases studied here.

\subsection{Water Resources}

Neither Plan Costa nor Mapa follow up on specific hydrologic features, but Sicodesi does. However, so far the Corrales case has not assessed if silviculture, by design, accomplished its targets of reduced erosion, reduced flooding, or any other water-related goal.

Mapa places a high priority on using the best available road design. Roads are not evaluated in Mexico, so there is no comparison between Llanito and the two alternate cases, Corrales and Cruz del Tuito. However, considering the theoretical support that low impact roads have on water resources [28], it is expected that Mapa is carrying out a more responsible management of silviculture and water interactions [22,29,30].

Mapa specifies road engineering in detail, including a set of best management practices such as proper culvert design, ample road lighting, outsloped roads, road closure after harvest, and so on. One item worth mentioning is the fact that Llanito roads realigned during the study period (2002 to 2011) needed no major maintenance at the following entry, which is underway (2012 to 2022).

In the case of Plan Costa, harvest is concentrated on groups of trees. Terrain tends to be gently sloped, so little erosion was seen during the second forest inventory, attributable to roads or timber harvesting. Most logging is done manually, so fewer roads are needed for small vehicles to haul products. For these reasons, water resources in Cruz del Tuito might deserve better grades than Sicodesi, though not better than Llanito's.

Important resources like irrigation and urban uses of water do not benefit from silvicultural practices or forest policies that are designed to secure water quality, volume, or seasonality because commercial timber land is only a small fraction ( $8 \%$ ) of all terrain where water flows on its way to the intended user. However, water quality does have a significant impact on habitat for aquatic flora and fauna, and it sustains vital processes for all vegetation, particularly riparian communities [31].

\subsection{Wildlife}

Flora and fauna are regional attributes. The forest properties studied are small, as small as most other ownerships in Mexico. Hence, there is no way to report on the effect of silviculture on wildlife.

From management plans and reports of disturbances it is possible to rank the methods from a wildlife perspective. Sicodesi follows an aggressive policy to liquidate oldgrowth, reduce incidents of pests, diseases and wildfire, to maintain as much of the land in the younger age categories, increase density 
closer to full occupation, maintain even spacing, and favor the most commercial and productive species. Plan Costa, conversely, uses a limited portion of the forest, removing groups of trees but leaving most of the ground untouched. A great deal of operations in Plan Costa are manual or animal logging, and roads are the minimum needed for small trucks. In Mapa there is a definite policy to increase the least frequent stand structures (mature, and regeneration), and a specific prescription for each scenario, from ridge tops to riparian influence zones.

As expected under these policies, forest inventory surveys report reduced habitat diversity in Sicodesi, and a significant increase in structural diversity and connectivity in Mapa. Plan Costa might have had a continuation of the original wild conditions except for the intense root rot attacks on parota (Enterolobium cyclocarpum). Since parota represented more than $45 \%$ of the initial stocking, losses have changed drastically the stand density, opened the overstory, liquidated parota volume (down to 18\%), and lost most of the very large trees in the stand. Most of this dead material was salvaged, so actual removals appear larger than expected, although commercial entries were few and close to the plan.

\subsection{Science and Culture}

Sicodesi was the forest scheduling tier of a grand design in the latter part of the 20th century that was spearheaded by the federal government. The overall aim of this grand scheme was to position federal institutions as leaders setting the direction and pace of forest sector development. Forest communities were invited to take over all parts of the value chain in the timber industry, including sawmills and other manufacturing. The scale of this program justified a considerable investment in the developed of the Sicodesi decision support software. The algorithm in Sicodesi followed general guidelines from a preliminary normal yield table. Prescriptions were drafted on site in every stand, after suggestions from a silviculture simulation's model outputs, adjusted by field conditions, and policies regarding multiple natural resources, environmental impacts, and socioeconomic goals. Sicodesi is the oldest and also the most complex, sophisticated, and widely used of the three methods presented here.

Plan Costa is a simple solution to the many joint decisions faced in tropical forests. The Plan Costa scheme calls for the individualized management of each of about a hundred woody species, palms, and other plants that grow under different forest types (medium and low tropical forest, palm groves, brushland, oak forest). The sophistication in this method stems from the successful regeneration of all commercial species.

Mapa's strong conceptual feature is in the renewal of the ecological basis of silviculture. Forest culture among the public and in the academic institutions is bogged down in imaginary realities created during the time of environmental awareness of middle 20th century. Some old beliefs are rooted in the notion that forests better fulfill societal mandates if left without cultivation; these explanations go against current forest ecology knowledge. It is quite difficult to move the public mind to accept disturbances as part of the natural set of desirable events. Also, the public and academic circles are unaware of the disproportional differences in impact represented by silviculture, natural disturbance events, roads and logging equipment. Evidence [29,30] puts roads at the top of the list of environmental concerns, a notion that is unacceptable to public and opinion leaders. Stakeholders like the forest owners and professional foresters regard roads as a negligible concern. Treatments, even those that specifically mimic natural processes, such as stand replacement, are rejected by the media and public opinion [32,33]. As in most 
other innovation cases, time might help settle these issues, but in the meantime Mapa has no more public support than any other forest technology.

Regardless of public opinion, historic trends of the last 30 years in the region point out the increasing importance of tourism [23]. Landscape features that attract visitors include the presence of natural forests. As long as the forest has a dense canopy cover, it is not required that the forest should be efficiently managed for timber. This fact has been clearer in the coastal tropical forests. If current preferences could have been forecasted 30 years ago, silviculture emphasis on simplified, homogeneous structures might have changed to diversified stand structures. More of the harvestable value could have been removed, and concern for disturbances might have been downgraded. A similar short-sighted attitude has been common across the world [3]. Instead of setting management goals for commodity production, a strategy to deal with changing social preferences and historic events could have been wiser [34].

The three cases studied can be considered community forestry because they are managed that way, and not as industrial or public forests. They are private lands; the public has no access to the forest, although these three ownerships are crossed by public roads. A permit from the owner is required for visitors, and they are forbidden to hunt game or collect plants or non-timber forest products. Cattle grazing is tolerated as long as the cattle owner negotiates terms of use with the forest owner. Forest owner policy is to eradicate grazing in the long run. The location of these forests also discourages visitors and contemplative uses of the land [17]. In general, the use of land resources is in the hands of the forest owner, so there is a scant contact of most other persons with wildlands in general.

The public in Jalisco has remained suspicious of all silvicultural activities. Fire and pest events are seen as avoidable losses demanding additional regulation and strong enforcement [33]. University institutions and academic groups are actively seeking to set public opinion in favor of additional legislation restricting silviculture, and demanding new private natural easements. At the same time, the public and decision makers have rejected the possibility of having public lands for conservation, or for any other purpose. Government is considered an inefficient landlord. In general, public opinion and government leaders admit that forest communities have the legal right to use land resources, though there is a strong preference for gradually phasing out timber harvesting. Household income from forestry is being replaced by nature tourism and subsidies. The public mandate is for maintaining the current forest structure and boundaries as if a managed second forest would hold all the values of a pristine primary forest [12].

Stability of the total forested area and the productive forest area are the accomplishments that are closer to the social mandate. However, the outcome seems strongly related to land owner preferences and behavior. Design features in the technology explain little of this performance.

Since Mapa is the only case with explicit financial performance criteria, it was expected that choices in Mapa would be stricter about which investments are worthwhile pursuing, and still set the path to an ecologically richer forest structure. Partial success in El Llanito in improving the non-timber concerns was a token of progress towards fulfilling the social mandate in terms of stewardship of non-market forest values. The change seen might not be enough to fully respond to cultural demands; it is only a sign pointing the road for the future, at least while Mexican forests remain in private hands. Recognition of the practical importance of financial assessments as seen in the Mapa/El Llanito case suggest that future options must explicitly address the private nature of Mexican forestry, and it might 
be that more effective methods could be developed if they rely on microeconomic theory about the public impact of private forest practices, relative to the private impacts of regulatory takings. The size of these regulatory impacts is massive because there is no upper bound on liability of forest owners whose forests have suffered any damage to material or cultural assets of public importance, such as protected endangered species, regardless of the level of actual effect of silviculture from such events.

\subsection{Lessons Learned}

Adding all merit criteria, an overall relative grade can be subjectively assigned to each of the three methods (Table 1). It is interesting to note that achievements of all three methods are somehow similar, and they relate to technical attributes. Disappointing performance, on the contrary, was characteristic of attributes related to societal expectations. This situation recognizes that innovations like those in Mapa are driving the forest closer to the socially desirable state, but much progress is still necessary to comply with essential aspects of the social mandate. Many of those goals are beyond the scale of the managed forest, particularly wildlife and water concerns. New technology and probably also new legislation will be required, since today in Mexico and in the world in general, far-reaching policy instruments for guiding landscape features at a regional scale are rather weak. Cooperation, leadership, and incentives available today in Mexico and most other countries do not control events that define the desired forest condition [35].

Table 1. Relative grading of performance of Sicodesi, Plan Costa, and Mapa methods. Full compliance (3), partial compliance (2), poor compliance (1), no capability (0) for a given criterion.

\begin{tabular}{cccc}
\hline Criteria & Sicodesi & Plan Costa & Mapa \\
\hline Tenure & 3 & 3 & 3 \\
Forest area & 3 & 3 & 3 \\
Rule of law & 3 & 3 & 3 \\
Inventory & 3 & 3 & 3 \\
Harvest & 3 & 3 & 3 \\
Health & 3 & 3 & 2 \\
Water & 1 & 1 & 2 \\
Biodiversity & 1 & 1 & 2 \\
Land value & 1 & 1 & 3 \\
Recreation & 1 & 1 & 1 \\
Public opinion & 1 & 1 & 1 \\
Innovation & 3 & 3 & 3 \\
Incidents & 1 & 2 & 3 \\
AVERAGE & 2.1 & 2.2 & 2.5 \\
\hline
\end{tabular}

The highly technical scope of most forest management methods in the world may suggest that the Mexican scenario may repeat in other forest countries. There is a need for technology to support land management policy at regional scales, where most of the actual concerns occur [10]. Considering Kahneman's [36] theoretical work about the psychology of decision making, it might be possible that the collective image that people have about the role of forests was built without a connection to reality 
and may be unreachable. If so, a breach between accomplishments and expectations will always exist. The role of forestry as science and technology might not be to close the gap by providing better forest management, but rather to explain to society the limitations that limit forest land's potential to meet social expectations.

\section{Conclusions}

Expectations about continuous forest presence, continuous output flow and income are goals that were achieved in all cases studied. Steadfast willingness of land owners and professional advice available might have more to do with this achievement than the techniques themselves, though it also shows that Sicodesi, Plan Costa, and Mapa are mature, solid technologies.

Plan Costa, Sicodesi and Mapa do not contain a comprehensive set of elements to address non-timber values. Mapa incorporated management of non-timber values at the property scale, but it has no influence over regional events. So far it is not reasonable to expect that social goals will be met. Traditional methods such as Sicodesi and Plan Costa are definitely driving the forest away from socially desirable goals. Mapa is moving forest features towards those goals, but since it has a mandate to self-finance conversion, the pace of progress is middling and insufficient.

\section{Author Contributions}

Martin Alfonso Mendoza wrote the paper. Juan José Fajardo designed management plans for El Llanito and Corrales, and Gonzalo Curiel designed the management plan for C.I. Comunidad Indígena Santa Cruz del Tuito. Francisco Domínguez analyzed the Corrales case. Maribel Apodaca analyzed the Cruz del Tuito case. María Guadalupe Rodríguez-Camarillo analyzed El Llanito case. Jesús Zepeta was in charge of forest inventory and GIS data bases. All authors discussed draft versions and agreed on the ideas presented in this paper. All authors are equally responsible for arguments presented and conclusions reached.

\section{Conflicts of Interest}

The authors declare no conflict of interest.

\section{References}

1. Mendoza, B.M.A. Harvest Regulation for Multiresource Management, Old and New Approaches. In Proceedings of the Sustaining Forests, Sustaining People, The Role of Research, XXIV IUFRO World Congress, Salt Lake City, UT, USA, 5-11 October 2014.

2. Osmaston, F.C. The Management of Forests; George Allen and Unwin: London, UK, 1968.

3. Von Gadow, K.; Nuutinen, T.; Kellomäki, S. Adaptive design of Forested Landscapes. In Designing Green Landscapes; Von Gadow, K., Pullala. T., Eds.; Springer: Berlin, Germany, 2010; pp. 3-30.

4. Davis, L.S.; Johnson, N.K.; Bettinger, P.; Howard, T.E. Forest Management to Sustain Ecological, Economic and Social Values, 4th ed.; Waveland Press: Long Grove, IL, USA, 2001.

5. Clawson, M. Decision Making in Timber Production, Harvest, and Marketing; Resources For the Future: Washington, DC, USA, 1977. 
6. Faustmann, M. Calculation of the value which forest land and immature stands possess for forestry. In Faustmann and the evolution of the Discounted Cash Flow; Linnard, W., Ed.; Commonwealth Forestry Institute: Oxford, UK, 1969.

7. Hof, J. Proactive Forest Management; Academic Press: San Diego, CA, USA, 1993; pp. 1-189.

8. Klemperer, W.D. Forest Resource Economics and Finance; McGraw-Hill: New York, NY, USA, 1966.

9. Lippke, B.; Bruce Bare, B.B.; Xu, W.; Moffet, J.; Bill Turner, B. The joint production of timber and environmental values, demonstration for the west side of Washington State. Global concerns for forest resource utilization. For. Sci. 1999, 62, 295-309.

10. Daily, C.G.; Alexander, S.; Ehrlich, P.R.; Goulder, L.; Loubchenco, J.; Matson, P.A.; Mooney, H.A.; Postel, S.; Schneider, S.H.; Tilman, D.; et al. Ecosystem services: Benefits supplied to human societies by natural ecosystems. Issues Ecol. 1997, 2, 1-16.

11. Del Angel-Mobarak, G. El medio forestal de México. In La Comisión Nacional Forestal en la Historia y el Futuro de la Política Forestal de México; del Angel, G., Ed.; Centro de Investigación y Docencia Económicas, Comisión Nacional Forestal: Ciudad de México, Mexico, 2012; pp. 35-77.

12. Mendoza, B.M.A. El mundo forestal global: un balcón para mirar a México globalmente. In $L a$ Comisión Nacional Forestal en la Historia y el Futuro de la Política Forestal de México; del Ángel, G., Ed.; CIDE, Comisión Nacional Forestal: Ciudad de México, México, 2012; pp. 81-113.

13. Moreno-Sánchez, R.; Torres-Rojo, J.M. Decision Support Systems for Forest Management in Mexico: Their Characteristics and Context for Their Creation and Evolution. In Decision Support Systems in Agriculture, Food, and the Environment: Trends, Applications and Advances; Manos, B., Paparrizos, K., Matsatsinis, N., Papathanasious, J., Eds.; Information Science Reference: Hershey, NY, USA, 2010; pp. 74-100.

14. Domínguez-Hernández, F.; Mendoza, M.A.; López-Mata, L. Sistema de conservación y desarrollo silvícola, lecciones de un caso de aplicación de manejo forestal en Jalisco, México. Juyyaania 2013, $1,85-103$.

15. Curiel-Alcaráz, G.M.; Mendoza, M.A. Método de Ordenación PLAN COSTA de Jalisco. In Talleres Regionales Aspectos Técnicos del Manejo Forestal Sustentable; Ríos, R., Ed.; Secretaría de Medio Ambiente y Recursos Naturales: Ciudad de México, Mexico, 2007.

16. Mendoza, B.M.A.; Fajardo, J.J.; Zepeta, J. Manejo de paisaje, una interpretación práctica. Bois For. Trop. 2005, 285, 48-54.

17. Mendoza, B.M.A.; Fajardo, J.J.; Zepeta, J. Landscape based forest management-A real world case study from Mexico. For. Ecol. Manag. 2005, 209, 19-26.

18. Oliver, C.D.; Larson, B.C. Forest and Stand Dynamics; Mc Graw-Hill: New York, NY, USA, 1990.

19. Apodaca-Martínez, M.; Curiel-Alcaraz, G.M.; Mendoza-Briseño, M.A.; Vargas-Mendoza, M.; Valdez Hernández, J.I.; Platas Rosado, D.E. El plan costa como una mejor opción de manejo de especies forestales tropicales de Jalisco. Rev. Mex. Cienc. For. 2014, 5, 10-25.

20. Joyce, P.M. Silviculture and forest management in France. Ir. For. 1973, 30, 29-43.

21. Rodríguez-Camarillo, M.G. Diseño de un Sistema Silvícola Para Conservación Natural Activa; Disertación doctoral, Colegio de Postgraduados: Montecillo, México, Mexico, 2011; pp. 1-65. 
22. Barnwell, J. Supreme Court recognizes merit of BMP's, but the need for a legislative fix remains. For. Source 2013, 18, 6.

23. Mendoza, B.M.A.; García-Moya, E.; Ángel-Pérez, A.L. del Desarrollo regional y conservación natural. Cienc. Desarro. 2002, 28, 42-47.

24. SARH. Guía del sistema de conservación y desarrollo silvícola SICODESI. In Talleres Regionales Aspectos Técnicos del Manejo Forestal Sustentable; Subsecretaría Forestal y de Fauna Silvestre, Secretaría de Agricultura y Recursos Hidráulicos (México): Ciudad de México, México, 2013; p. 259.

25. Putz, F.E.; Zuidema, P.A.; Synnott, T.; Peña-Claros, M.; Pinard, M.A.; Sheil, D.; Vanclay, J.K.; Sist, P.; Gourlet-Fleury, S.; Griscom, B.; et al. Sustaining conservation values in selectively logged tropical forests: the attained and the attainable. Conserv. Lett. 2012, 5, 296-303.

26. Duah-Gyamfi, A.; Swaine, E.K.; Pinard, K.A.; Swaine, M.D. Can harvesting for timber in tropical forest enhance timber tree regeneration? For. Ecol. Manag. 2014, 314, 26-37.

27. Curiel-Alcaraz, G.M. Programa de Manejo Forestal Para el Aprovechamiento De Recursos Forestales Maderables, Nivel Avanzado; Unidad de Manejo Forestal, SC. Secretaría de Medio Ambiente y Recursos Naturales: El Tuito, Jalisco, México, 2010.

28. SAF. Society of American Foresters. Ninth Circuit: Run-off from forest roads is "point source" pollution; Society of American Foresters. For. Chron. 2010, 15, 1.

29. Dykstra, D.P. Reduced impact logging: Concepts and issues. In Applying Reduced Impact Logging to Advance Sustainable Forest Management; Enters, T., Durst, P.B., Applegate, G.B., Kho, P.C.S., Man, G., Eds.; Corporate Document Repository, FAO: Regional Office for Asia and the Pacific, Bangkok, Thailand. Available online: http://www.fao.org/docrep/005/ac805e/ ac805e00.html (accessed on 1 November 2014).

30. Wilent, S. Symposium highlights benefits of best management practices, research. For. Source 2014 , 19, 1 .

31. Burton, T.A.; Smith, S.J.; Cowley, E.R. Multiple Indicator Monitoring (MIM) of Stream Channels and Stream Side Vegetation; Technical Reference 1737-23.BLM/OC/ST-10/003+1737+REV. Department of Interior, Bureau of Land Management, National Operations Center: Denver, CO, USA, 2011.

32. Del Castillo, A. Se mantendrá elevada la pérdida de bosque en Jalisco. Pérdida de bosque en Jalisco. Milenio. Jalisco, 4AGO2014. Available online: http://www.agustindelcastillo.com/2014/08/ se-mantendra-elevada-la-perdida-de-html (accessed on 1 November 2014).

33. Del Castillo, A. Sector forestal, una crisis sin precedentes. Milenio. Jalisco, 2014. Available online: http://www.milenio.com (accessed on 29 October 2014).

34. Franklin, J.; Forman, R. Creating landscape patterns by forest cutting: Ecological consequences and principles. Landsc. Ecol. 1987, 1, 5-18.

35. Blackman, A.; Raimondi, A.; Cubbage, F. Does forest certification in developing countries have environmental benefits? Insights from Mexican corrective action requests. Environment for Development Discussion Paper Series; Resources for the Future: Washington, DC, USA, 2014. Available online: http://www.rff.org/RFF/Documents/EfD-DP-14-09.pdf (accessed on 28 October 2014). 
36. Kahneman, D. Thinking, Fast and Slow; Farrar, Straus and Giroux: New York, NY, USA, 2011.

(C) 2015 by the authors; licensee MDPI, Basel, Switzerland. This article is an open access article distributed under the terms and conditions of the Creative Commons Attribution license (http://creativecommons.org/licenses/by/4.0/). 